\title{
Beban Candida dalam Saluran Cerna Anak
}

\author{
Hardi Hutabarat, ${ }^{1}$ Ida B. E. U. Wija, ${ }^{2}$ Forman E. Siagian, ${ }^{1}$ Retno Wahyuningsih ${ }^{1,3 *}$ \\ ${ }^{1}$ Departemen Parasitologi Fakultas Kedokteran Universitas Kristen Indonesia \\ ${ }^{2}$ Departemen Ilmu Kesehatan Anak Fakultas Kedokteran Universitas Kristen Indonesia \\ ${ }^{3}$ Departemen Parasitologi Fakultas Kedokteran Universitas Indonesia
}

\begin{abstract}
Abstrak
Mikrobiota terbesar pada tubuh manusia terdapat pada saluran cerna (70\%).Mikrobiota normal saluran cerna tersusun atas komposisi mikroorganisme yang unik dan berada dalam keadaan seimbang, didalamnya termasuk Candida spp., yang hidup sebagai komensal. Data tentang keberadaan Candida dalam usus terutama berasal dari orang dewasa, sedangkan data pada anak sangat jarang. Penelitian ini bertujuan untuk mengetahui keragaman spesies Candida dan bebannya pada saluran cerna anak. Untuk menghitung beban jamur, sebanyak 0,2 g tinja ditanam pada agar sabouraud dekstrosa (ASD). Beban jamur dihitung berdasarkan koloni yang tumbuh dan disesuaikan menjadi per gram tinja (colony forming unit - CFU/g tinja). Identifikasi Candida dilakukan berdasarkan koloni yang tumbuh pada medium CHROMagar Candida (Paris, France). Populasi penelitian adalah anak umur 0-18 tahun (sesuai kriteria WHO). Sampel berasal dari RT 10 dan 11, Kampung Pluis, Jakarta Selatan dan RT 4, 6 dan 9, Kelurahan Cawang. Sebanyak 61 sampel tinja ditanam pada medium, dan didapat 72 isolat dari 43 pertumbuhan yang berasal dari 54 anak sehat dan tujuh anak sakit, yang dirawat di Departemen Kesehatan Anak RS UKI dengan berbagai sebab. Isolat yang didapat terdiri atas Candida tropicalis, Candida albicans, Candida parapsilosis, dan Candida glabrata. Beban jamur 1-50 CFU ditemukan pada 18 pasien, diikuti oleh beban jamur 151-200 CFU pada tujuh pasien. Selain itu, ditemukan infeksi campuran (dua spesies) pada sembilan sampel dan 3 spesies pada tujuh sampel. Tinja anak sakit didominasi C. tropicalis, empat sampel memiliki campuran C. tropicalis dengan $C$. albicans, dan C. tropicalis dengan C. parapsilosis.
\end{abstract}

Kata Kunci: Candida, spesies, CFU, beban jamur

\section{Candida Load in the Children's Gastrointestinal Tract}

\begin{abstract}
The largest microbiota in the human body is found in the digestive tract (70\%). The microbiota in the digestive tract is normally composed of a unique composition of microorganisms and is in a balanced state, including Candida spp., which live as commensals. Data on the presence of Candida in the intestine, especially coming from an adult, while the data in children are very rare. This study aims to determine the diversity of Candida species and fungal burden on the children's digestive tract. To calculate the fungal load, $0.2 \mathrm{~g}$ of faeces were planted on sabouraud dextrose agar (ASD). The fungal load was calculated based on the growing colonies and adjusted to be per gram of faeces (colony forming unit - CFU/g of faeces). Candida identification was carried out based on the colonies that grew on the CHROMagar Candida medium (Paris, France). The study population was children aged 0-18 years (according to WHO criteria). Samples came from RT 10 and 11, KampungPluis, South Jakarta and RT 4, 6 and 9, Cawang. A total of 61 stool samples were planted on the medium, and obtained 72 isolates from 43 growths from 54 healthy children and seven children who were treated at the Children's Health Department of UKI Hospital for various reasons. The isolates obtained consisted of Candida tropicalis, Candida albicans, Candida parapsilosis, and Candida glabrata. 1-50 CFU fungal burden was found in 18 patients, followed by 151-200 CFU fungal burden in seven patients. In addition, there were mixed infections (two species) in nine samples and three species in seven samples. The stool of the sick children was predominantly C. tropicalis, four samples had a mixture of C. tropicalis with C. albicans, and C. tropicaliswith C. parapsilosis.
\end{abstract}

Keywords: Candida, species, CFU, fungal burden

*RW: Penulis Koresponden; E-mail: retnet2002@gmail.com 


\section{Pendahuluan}

Mikrobiota terbesar pada tubuh manusia terdapat pada saluran cerna (70\%). Diperkirakan terdapat $10^{14}$ sel bakteri atau $100 \times$ jumlah gen pada genome manusia. ${ }^{1}$ Kolonisasi mikroba pada saluran cerna manusia dimulai pada saat lahir, ketika manusia pertama kali berhubungan langsung dengan lingkungan melalui jalan lahir. ${ }^{2}$

Mikrobiota pada saluran cerna memiliki banyak kegunaan bagi manusia, seperti sintesis nutrisi (vitamin), metabolisme karbohidrat, lemak dan proses detoksifikasi. ${ }^{2}$ Mikroba juga mencegah kolonisasi mikroorganisme patogen dengan cara bersaing untuk mendapatkan makanan dan tempat melekat pada dinding saluran cerna. ${ }^{3}$

Mikrobiota normal saluran cerna tersusun atas komposisi mikroorganisme yang unik dan berada dalam keadaan seimbang, didalamnya termasuk Candida spp., yang hidup sebagai komensal. Dalam kondisi komensal gen penyandi virulensi dalam keadaan dormant sehingga tidak terjadi aktivitas patogenik. Salah satu kondisi yang mengaktifkan gen tersebut adalah faktor risiko yang antara lain adalah kolonisasi jamur. ${ }^{4,5}$

Schulze dan Sonnenborn ${ }^{6}$ menemukan pada $70 \%$ orang dewasa sehat ditemukan jamur pada saluran cernanya. Pada lambung didapatkan sekitar $0-10^{2} \mathrm{CFU} / \mathrm{mL}$, jejunum sebanyak $0-10^{2} \mathrm{CFU} / \mathrm{mL}$, ileum sebanyak $10^{2}-10^{3} \mathrm{CFU} / \mathrm{mL}$ dan pada kolon $10^{2}-10^{6}$ $\mathrm{CFU} / \mathrm{mL}$. Sebagian besar jamur tersebut bersifat aerobik atau fakultatif anaerobik.

Data tentang kolonisasi jamur pada saluran cerna orang dewasa telah banyak dilaporkan, namun tidak demikian halnya dengan anak. Pada panenelitian ini akan dilaporkan kolonisasi Candida pada anak sehat maupun yang dirawat di rumah sakit.

\section{Bahan dan Cara}

Desain penelitian studi deskriptif cross sectional. Penelitian dilakukan dalam kurun waktu tiga bulan, sejak bulan November 2016 sampai Januari 2017. Pengambilan sampel dilakukan di wilayah kampong Pluis RT 010 dan RT 011 Jakarta Selatan, Kelurahan Cawang Jakarta Timur yaitu RT 04, RT 06 dan RT 09 serta pasien anak rawat inap Rumah Sakit Umum Universitas Kristen Indonesia. Pemeriksaan Laboratorium dilakukan di Laboratorium Parasitologi Fakultas Kedokteran Universitas Kristen Indonesia. Izin melaksanakan penelitian diperoleh dari Komite Etik penelitian Fakultas Kedokteran Universitas Kristen Indonesia dengan nomor surat no.001/EtikPenelitian/FKUKI/2016. Untuk setiap calon responden diberikan penjelasan memadai tentang penelitian sebelum dimintakan persetujuan (informed consent).

Subjek dibagi menjadi dua kelompok, kelompok sehat diwakili oleh anak-anak yang tinggal di Cawang dan Kampung Pluis sedangkan anak-anak yang sakit diwakili oleh pasien rawat inap di RSU UKI. Sampel yang digunakan adalah tinja yang berasal dari kedua kelompok tersebut. Untuk menghitung beban jamur, sebanyak 0,2 g tinja ditanam pada agar sabouraud dekstrosa (ASD). Beban jamur dihitung berdasarkan koloni yang tumbuh dan disesuaikan menjadi per gram tinja (colony forming unit - CFU/g tinja). Identifikasi Candida dilakukan berdasarkan koloni yang tumbuh pada medium CHROM agar Candida (Paris, France).

\section{Hasil}

Penelitian dilakukan selama tiga bulan di laboratorium Parasitologi FK UKI. 
Pemeriksaan dilakukan terhadap 61 sampel tinja yang berasal dari 55 anak sehat dan tujuh anak sakit. Persetujuan tertulis (informed consent) ditandatangani oleh walinya setelah mendapat penjelasan penelitian yang memadai.

\section{A. Karakteristik Subyek Penelitian}

Sebagian besar subyek penelitian adalah laki-laki 35 anak $(57,4 \%)$ dan perempuan 26 anak (42,6 persen) (Tabel 1). Usia subyek penelitian paling banyak berada dalam rentang usia 0-4 tahun (24 anak/39,3\%) diikuti oleh kelompok 5-8 tahun (21 anak/34,4\%). Dari total 61 subyek penelitian, tujuh pasien $(11,5 \%)$ merupakan pasien yang dirawat di bangsal anak RSU UKI dengan diagnosis beragam dan terdapat 54 subyek sehat $(88,5 \%)$

Tabel 1. Karakteristik Demografis dan Klinis Subyek Penelitian

\begin{tabular}{llcc}
\hline Karakteristik & & n & Presentase(\%) \\
\hline Jenis Kelamin & & & \\
& Laki-Laki & 34 & 55,7 \\
Usia & Perempuan & 27 & 44,3 \\
& & & \\
& 0-4 Tahun & 24 & 39,3 \\
& 5-8 Tahun & 21 & 34,4 \\
Manifestasi & 9-12 Tahun & 12 & 19,7 \\
Klinis & 13-16 Tahun & 4 & 6,6 \\
& & & \\
& Sehat & 54 & 88,5 \\
& Sakit & 7 & 11,4 \\
\hline
\end{tabular}

Tabel 2 menggambarkan beban jamur pada subyek yang diteliti. Dari tujuh subyek sakit didapatkan tiga sampel tinja yang memiliki beban jamur sebesar 200-800 koloni dan sebanyak dua sampel tinja memiliki beban jamur sebesar 1-50 koloni serta dua koloni yang tidak terdapat pertumbuhan jamur. Pada 54 subyek sehat, didapatkan lima sampel tinja $(9,2 \%)$ dengan jumlah koloni jamur yang tidak dapat dihitung dan satu sampel $(1,8 \%)$ dengan beban jamur sebesar 200-800 koloni. Berdasarkan uji statistik terdapat perbedaan yang signifikan $(p=0,005)$ antara kondisi subyek dengan beban jamur tetapi hal ini perlu dikaji lebih dalam karena keterbatasan subyek sakit pada penelitian ini.

Tabel 2. Profil Beban Jamur berdasarkan Kondisi Subjek

\begin{tabular}{lccc}
\hline CFU/g tinja & \multicolumn{2}{c}{ Kondisi subyek } & Total \\
\hline & Sehat & Sakit & \\
Tidak Tumbuh & 16 & 2 & 18 \\
1-50 koloni & 16 & 2 & 18 \\
51-100 koloni & 3 & 0 & 3 \\
101-150 koloni & 6 & 0 & 6 \\
151-200 koloni & 7 & 0 & 7 \\
200-800 koloni & 1 & 3 & 4 \\
Tidak Terhitung & 5 & 0 & 5 \\
\hline Total & 54 & 7 & 61 \\
\hline
\end{tabular}

(Chi square, $p=0,005$ )

\section{B. Identifikasi Jamur}

Tabel 3. Hasil Identifikasi Spesies pada Medium CHROMagar

\begin{tabular}{lcc}
\hline \multicolumn{1}{c}{ Spesies } & CHROMagar & $\mathbf{\%}$ \\
\hline C.tropicalis & 30 & 41,6 \\
C.albicans & 22 & 30,5 \\
C.parapsilosis & 10 & 13,8 \\
C.glabrata & 10 & 13,8 \\
\hline Total & $\mathbf{7 2}$ & $\mathbf{1 0 0}$ \\
\hline
\end{tabular}

Hasil pemeriksaan tinja pada medium CHROMagar didapatkan hasil seperti di Tabel 3. Dalam penelitian ini, dari 61 sampel tinja yang diperiksa dan didapatkan 72 isolat Candida. Isolat tersebut terdiri atas 30 isolat C. tropicalis, 22 isolat C. albicans, 10 isolat C. parapsilosis dan 10 isolat C. glabrata. (Tabel 4). 
Tabel 4. Infestasi Spesies Tunggal dan Campuran

\begin{tabular}{lcc}
\hline \multicolumn{1}{c}{ Spesies } & Jumlah & Presentase(\%) \\
\hline Spesies Tunggal & $\mathbf{2 5}$ & $\mathbf{4 0 , 9}$ \\
C.tropicalis & 15 & 24.6 \\
C.albicans & 5 & 8.2 \\
C.parapsilosis & 2 & 3.3 \\
C.glabrata & 3 & 4.9 \\
Spesies Campuran & $\mathbf{2 0}$ & $\mathbf{3 2 , 7}$ \\
C.tropicalis + C.albicans & 6 & 9.8 \\
C.tropicalis + C.parapsilosis & 3 & 4.9 \\
C.albicans + C.glabrata & 4 & 6.6 \\
C.tropicalis + C.albicans + C.parapsilosis & 3 & 4.9 \\
C.tropicalis + C.albicans + C.glabrata & 2 & 3.3 \\
C.albicans + C.parapsilosis + C.glabrata & 1 & 1.6 \\
C.tropicalis + C.albicans + C.parapsilosis & 1 & 1.6 \\
Tidak ada pertumbuhan & $\mathbf{1 6}$ & $\mathbf{2 6 . 2}$ \\
\hline Total & $\mathbf{6 1}$ & $\mathbf{1 0 0 . 0}$ \\
\hline
\end{tabular}

Tabel di atas menunjukkan komposisi spesies isolat tunggal dan kombinasi antar spesies Candida; pada kombinasi antar spesies, maka ada yang dibentuk oleh dua spesies, dan ada juga yang dibentuk oleh tiga spesies.

\section{Diskusi}

Faktor yang mempengaruhi kolonisasi Candida dalam saluran cerna adalah kompetisi nutrisi dengan bakteri, pengaruh sistem imun pejamu dan aktivitas genetik jamur. $^{7}$ Kolonisasi diketahui sebagai awal infeksi baik yang sifatnya sistemik seperti kandidemia maupun yang lebih bersifat lokal. Penelitian pada hewan memperlihatkan bahwa keberadaan Candida dalam saluran cerna mencegah penyembuhan proses peradangan dalam usus. ${ }^{7,8}$ Sehingga pengetahuan tentang keberadaan Candida dalam usus sangat penting pada pejamu imunokompeten sekalipun.

Khatib et al. ${ }^{9}$ melakukan penelitian mengenai beban jamur pada subyek relawan dan subyek yang dirawat inap. Ditemukan ada perbedaan yang signifikan antara kedua subyek, pada pasien rawat inap didapatkan beban jamur yang lebih tinggi.
Pada penelitian ini didapat kolonisasi Candida pada 70,5\% subyek penelitian baik pada subyek sehat maupun yang dirawat di rumah sakit. Pada pasien sehat keberadaan Candida tidak akan memberikan efek patogenik karena sistem kekebalan yang intak, sementara pada anak yang dirawat dirumah sakit pemberian antibiotik maupun perubahan dalam pola makan akan mempengaruhi respons Candida terhadap lingkunganya. Keberadaan Candida dalam saluran cerna pada pejamu imunokompeten sekalipun menggambarkan interaksi antara Candida dan lingkungannya dalam hal ini lumen dan dinding usus pejamu.

Spesies terbanyak yang diidentifikasi dalam penelitian ini adalah $C$. tropicalis sebesar $41,6 \%$ diikuti oleh $C$. albicans sebesar 30,5\%. Gurleen dan Savio ${ }^{10}$ juga meneliti mengenai Candida pada sampel tinja, perbedaannya mereka menghubungkan antara temuan Candida dengan gejala diare. Hasilnya 46,7\% ditemukan C. albicans dan33,3\% C. tropicalis. Hasil penelitian ini semakin mendukung bahwa mulai terjadi pergeseran koloni Candida dalam saluran cerna. 
Penelitian lain di Jerman menemukan bahwa $C$. albicans merupakan spesies yang paling banyak ditemukan dalam tinja manusia, baik dalam keadaan sehat maupun diare. ${ }^{10,11} \mathrm{Hal}$ itu berbeda dengan hasil penelitian ini, perbedaan tersebut mengindikasikan bahwa di wilayah penelitian mulai terjadi pergeseran spesies di dalam saluran cerna atau perbedaan tersebut merupakan perbedaan geografis.

Pergeseran spesies mungkin terjadi akibat berbagai faktor misalnya penggunaan obat antifungal. Selain itu pergeseran spesies Candida dalam saluran cerna dapat mempengaruhi penyebab infeksi sistemik dari semula C. albicans menjadi C. tropicalis. Disisi lain, bila secara geografis memang berbeda maka hal itu juga menunjukkan bahwa jenis jamur dalam saluran cerna dipengaruhi oleh wilayah tinggal seseorang.

Hasil penelitian ini menemukan bahwa C. tropicalis merupakan spesies yang paling banyak ditemukan. Chowdhary et $a l,{ }^{12}$ melaporkan suatu outbreak kandidemia yang disebabkan oleh $C$. tropicalis dan melibatkan 16 neonatus. Seluruh neonatus mendapatkan hyperalimentation dan sekurangnya mendapatkan satu antibiotik. Candida tropicalis di identifikasi dari 16 sampel darah neonatus dan 14 sampel urin.

Penelitian oleh Wahyuningsih et al,menemukan bahwa sepsis Candida pada neonatus paling sering disebabkan oleh $C$. tropicalis. ${ }^{13}$ Selama ini di Jakarta diketahui bahwa $C$. albicans merupakan sepsies paling patogen, namun telah terjadi pergeseran ke arah Candida non C. albicans yang sering kali dihubungkan dengan pengobatan memakai derivat azol yakni flukonazol. ${ }^{14}$

Saluran cerna umumnya dikolonisasi oleh satu spesies Candida, namun juga ditemukan kolonisasi oleh $>1$ spesies. Pada 25 sampel tinja ditemukan spesies tunggal dan yang paling banyak ditemukan adalah C. tropicalis $(24,6 \%)$. Sebanyak 20 sampel tinja didapatkan spesies campuran $(>1$ spesies Candida), 13 dari 20 sampel (32,7\%) didapatkan spesies campuran yang terdiri dari dua spesies dan tujuh dari 20 sampel didapatkan spesies campuran yang terdiri atas tiga spesies Candida (Tabel 4).

Berdasarkan studi Pfaller et al, ${ }^{15}$ dari 2496 pasien yang mengalami invasive candidiasis terdapat 111 infeksi $(4,4 \%)$ yang melibatkan lebih dari dua spesies Candida. Studi lain yang dilakukan Nace et $a l,{ }^{16} 40(7,6 \%)$ dari 526 pasien mengalami kandidemia yang disebabkan oleh lebih $>2$ spesies Candida atau disebut sebagai multiple-species candidemia (MSC). Kombinasi yang sering ditemukan adalah $C$. albicans dan C. glabrata (sebanyak 15 kasus atau 37,5\%), C. albicans dan C. parapsilosis (sebanyak 8 kasus atau 20\%) dan C. glabrata dengan $C$. krusei (sebanyak 5 kasus atau $12,5 \%)$.

Multiple-species candidemia (MSC) mungkin akan menjadi tantangan dalam hal tatalaksananyakarena diperlukan pengobatan yang efektif dan aman. Penemuan kolonisasi $>1$ spesies pada penelitian ini merujuk pada kemungkinan terjadinya MSC bila kelak ditemukan faktor risiko untuk infeksi invasif pada anak-anak tersebut.

\section{Kesimpulan}

Penelitian ini mendapatkan hasil bahwa kolonisasi jamur ditemukan pada sebagian besar subyek yang diteliti dan mayoritas (29,5\%) beban jamur sebesar 1-50 CFU/g tinja dan 8,2\% sampel didapatkan beban jamur dengan jumlah koloni tidak terhitung. Spesies terbanyak yang diisolasi adalah C. tropicalis, diikuti oleh C. albicans, $C$. parapsilosis, dan C. glabrata.

\section{Daftar Pustaka}

1. Matamoros S, Leguen CG, Vacon FL, Potel G, Cochetiere MFL. Development of intestinal microbiota in infants and its impact on health. Trends Microbiol. 2013; 1-7 
2. Rocha CS, Azevedo M, Pontes DS, Agresti PM, Pereira PB, Castro CP, et al.Human GI tract microbiota in health and disease: a focus on inflammatory bowel diseases. Innovative Immunol. 2015; 1-38

3. Conrad R, Vlassov AV. The human microbiota: composition, functions, and therapeutic potential. Med Sci Rev. 2015; 2: 1-12

4. Huffnagle GB, Noverr MC. The emerging world of the fungal microbiome. Trends Microbiol. 2013; 21(7): 334-41

5. Wang ZK, Yang YS, Stefka AT, Sun G, Peng LH. Review article: fungal microbiota and digestive diseases. Aliment Pharmacol Ther. 2014; 39: 751-66

6. Schulze J, Sonnenborn U. Yeasts in the gut: from commensals to infectious agents. Deutsch Arztebl Int. 2009; 106: 837-42.

7. Payne S, Gibson G, Wynne A, Hudspith $\mathrm{B}$, Brostoff J, Tuohy $\mathrm{K}$. In vitro studies on colonization resistance of human gut microbiota to Candidaalbicans and the effects of tetracycline and Lactobacillus plantarum LPK. Curr Issues Intest Microbiol. 2003; 4: 1-8

8. Forbes D, Ee L, Camer-Pesci P, Ward PB. Faecal candida and diarrhoea. Arch Dis Child. 2001; 84: 328-31

9. Khatib R, Riederer KM, Ramanathan J, Baran J. Faecal fungal flora in healthy volunteers and inpatients. Mycoses. 2001; 44: 151-6
10. Gurleen K, Savio R. Prevalence of Candida in diarrhoeal stools. J Dental Med Sci. 2016; 15(4): 47-9

11. Jobst D, Kraft K. Candida species in stool, symptoms and complaints in general practice- a cross-sectional study of 308 outpatients. Mycoses. 2006; 49: 415-20

12. Chowdhary A, Becker K, Fegeler W, Gugnani HC, Kapoor L, Randhawa VS et al. An outbreak of candidemia due to Candida tropicalis in a neonatal intensive care unit. Mycoses. 2003; 46: 269-75

13. Wahyuningsih R, Rozalyani A, El Jannah SM, Amir I, Prihartono J. Kandidemia pada neonatus yang mengalami kegagalan terapi antibiotik. Maj Kedok Indon. 2008; 58: 110-5.

14. Wahyuningsih R, Freisleben HJ, Sonntag HG, Schnitzler P. Simple and Rapid Detection of Candida albicansDNA in Serum by PCR for Diagnosis of Invasive Candidiasis. JClin Microbiol. 2000. 38;8: 3016-21

15. Pfaller MA, Andes RD, Diekema DJ, Horn DL, Reboli AC, Rotstein C et al.Epidemiology and outcomes of invasive candidiasis due to nonalbicans species of candida in 2,496 patients: data from the prospective antifungal therapy (PATH) registry 2004-2008. Plos One. 2014; 9(7): 1-12

16. Nace HL, Horn D, Neofytos D. Epidemiology and outcome of multiple-species candidemia at a tertiary care center between 2004 and 2007. Diagn Microbiol Infect Dis. 2009; 64: 289-94 